\title{
Soil organic matter pools and carbon fractions in soil under different land uses
}

\author{
Daniele Vieira Guimarães ${ }^{a}$, Maria Isidória Silva Gonzaga a,*, Tácio Oliveira da Silva ${ }^{a}$, \\ Thiago Lima da Silva ${ }^{a}$, Nildo da Silva Dias ${ }^{b}$, Maria Iraildes Silva Matias ${ }^{c}$ \\ ${ }^{a}$ Agronomy Department, Federal University of Sergipe, São Cristóvão, SE 49100-000, Brazil \\ ${ }^{\mathrm{b}}$ Environmental Science Department, Federal University of Semiarid, Mossoró, RN 59625-600, Brazil \\ ${ }^{\mathrm{c}}$ Geology Department, Federal University of Bahia, Salvador, BA 40110-060, Brazil
}

\section{A R T I C L E I N F O}

\section{Article history:}

Received 11 November 2011

Received in revised form 14 June 2012

Accepted 29 July 2012

\section{Keywords:}

Humic substances

Soil quality

Tropical soils

\begin{abstract}
A B S T R A C T
Changes in tropical land use have profound effects on soil organic matter (SOM) status. It has been suggested that alterations in the different fractions of SOM are more effective in indicating changes in soil use than total soil organic matter content. The main objective of this study was to investigate changes in the content of humic substances in an Ultisol under different land uses, in the northeast region of Brazil. Soil samples were collected from the $0-10$ and $10-30 \mathrm{~cm}$ layers, in three agricultural areas (conventional coconut orchard, integrated coconut orchard, and citrus orchard). A native forest soil was used as reference. Organic $\mathrm{C}$ and total $\mathrm{N}$ were determined to characterize the SOM. Humic substances were chemically fractionated into fulvic acid, humic acid, and humin, based on solubility in acid and alkali. Significant loss (47.5\%) of soil organic matter was observed in the surface layers of the conventional coconut and citrus orchards, compared to the native forest. There was increased SOM content in the integrated coconut orchard soil, due to the presence of cover crops as well as management of crop residues. However, in the subsurface soil of the integrated coconut orchard, cultivation modified the distribution of the more labile fractions of the soil organic matter, as measured by the ratio between humic and fulvic acids ( $>1.0$ ), indicating a substantial loss of fulvic acids. The degree of humification was in the range $40-97 \%$. The distributions of the soil organic matter fractions varied in the ranges $12-32.5 \%$ (fulvic acids), 12-34.5\% (humic acids), and 40-69.5\% (humin).
\end{abstract}

(c) 2012 Elsevier B.V. All rights reserved.

\section{Introduction}

Soil organic matter (SOM) plays an important role in maintaining the productivity of tropical soils because it provides energy and substrates, and promotes the biological diversity that helps to maintain soil quality and ecosystem functionality. SOM directly influences soil quality, due to its effect on soil properties (Wendling et al., 2010). Once soil is cultivated for agricultural production, especially in the tropics and the semi-arid regions, SOM is rapidly decomposed due to modifications in conditions such as aeration, temperature, and water content (Ashagrie et al., 2007). This can affect many soil functions that are either directly or indirectly related to SOM, due to its capacity to retain water and nutrients. Although the breakdown rate of SOM can be faster in the tropics, regular inputs of organic amendments can promote a buildup of SOM (Follett, 2001).

Soils with low natural fertility and reduced water availability have been brought into production by means of high technology strategies including irrigation and the intensive use of fertilizers and

\footnotetext{
* Corresponding author. Tel.: +55 792105 6984; fax: +55 7921056929 .

E-mail address: mariaisisilva@gmail.com (M.I.S. Gonzaga).
}

pesticides. These management practices are very common in the tropics and can contribute to negative changes in soil quality, which should be investigated and monitored in order to reduce environmental impacts of agricultural activities as well as to promote a more sustainable use of soils. Due to the complexity of SOM compounds, the relationship between SOM characteristics and land use is poorly understood. Hence, knowledge of different pools of SOM should render the impacts of management practice more measurable.

Soil organic matter labile fractions have been used instead of total SOM as sensitive indicators of changes in soil quality (Bayer et al., 2002; Haynes, 2005), due to the many important interactions of these components in the soil system. Non-humic substances are labile compounds with relatively rapid turnover in soil, since they are readily utilized as substrates by soil microorganisms (Schmidt et al., 2011). Humic substances are more stable organic matter compounds, which make up a significant portion of the total soil organic C and N (Lal, 1994; Milori et al., 2002). Humic substances can improve soil buffering capacity, increase moisture retention, and supply plants with available micronutrients. Moreover, these compounds can also bind metals, alleviating both heavy metal toxicity and metal deficiency in soils (McCarthy, 2001).

Humic substances represent approximately $40-60 \%$ of the soil organic matter, and include three different fractions, defined 
according to different stability under acid hydrolysis and permanganate oxidation (Paul et al., 2001). Humin $(H)$ is the insoluble fraction of humic substances; humic acid (HA) is the fraction that is soluble under alkaline conditions; and fulvic acid (FA) is the fraction that is soluble under both alkaline and acidic conditions (Sutton and Sposito, 2005). The chemically reactive and refractory nature of humic substances contributes to their persistence in soils (Kiem and Kögel-Knabner, 2003; Rovira and Vallejo, 2007), as well as to their important role in nutrient flows through ecological systems, and $C$ emissions to the atmosphere (Lal, 2006). The relationship between concentrations of humic and fulvic acids (HA/FA ratio) is indicative of the potential mobility of $\mathrm{C}$ in the soil system. In general, sandy soils present higher ratios due to the solubility and selective loss of fulvic acids during the decomposition of SOM. The (HA + FA)/humin ratio indicates the degree of illuviation of SOM (Benites et al., 2003).

Changes in field management practices can alter the chemical properties of soil humic substances (Moraes et al., 2011). Spaccini et al. (2006) reported a progressive decrease in humic substance concentrations in soils that were converted from forest to arable farming. Such decrease is commonly attributed to microbial oxidation of the organic materials previously protected in the soil aggregates destroyed by cultivation. Most studies report a reduction in SOM and in its fractions when forest is converted to other land uses (Navarrete and Tsutsuki, 2008).

In northeast Brazil, the production of tropical fruits occupies a large area dominated by Ultisols. Management practices and yields vary among orchards, and soil quality has not been a focus of many farmers. In this region, there have been few studies that have addressed the impact of land use change on levels of humic substances in soils. The objective of this study was therefore to evaluate SOM characteristics as influenced by land use. The degree of humification of SOM, together with the contributions of the different humic substance fractions, was determined using an operationally defined chemical fractionation method, applied to an Ultisol cultivated with tropical fruit trees. The same soil type under native forest was used as a reference.

\section{Materials and methods}

\subsection{Site characterization and experimental design}

The work was conducted between August and October 2010 on irrigated farms in the state of Sergipe, in the northeast of Brazil. The climate is type BSh, according to the Koppen-Geiger classification (Peel et al., 2007), with dry summers and rainfall concentrated in the months of May to September. The mean annual precipitation and temperature are $1200 \mathrm{~mm}$ and $30^{\circ} \mathrm{C}$, respectively. The soil is an Ultisol (typic Hapludult). Physical and chemical properties of the soil under different uses are presented in Table 1. Soil texture

Table 1

Physical and chemical characterization of the soils under different land uses.

\begin{tabular}{lccllll}
\hline Land use & $\mathrm{pH}$ & $\begin{array}{l}\mathrm{P}^{*} \\
\left(\mathrm{mg} \mathrm{kg}^{-1}\right)\end{array}$ & $\begin{array}{l}\mathrm{CEC}^{\mathrm{a}} \\
\left(\mathrm{Cmol}_{\mathrm{c}} \mathrm{kg}^{-1}\right)\end{array}$ & $\begin{array}{l}\text { Sand } \\
(\%)\end{array}$ & $\begin{array}{l}\text { Silt } \\
(\%)\end{array}$ & $\begin{array}{l}\text { Clay } \\
(\%)\end{array}$ \\
\hline 0-10 cm & & & & & & \\
$\quad$ Conventional coconut & 6.4 & 21.0 & 6.40 & 76.4 & 15.8 & 7.78 \\
$\quad$ Integrated coconut & 6.5 & 54.1 & 10.4 & 80.1 & 12.4 & 7.55 \\
$\quad$ Citrus & 6.7 & 24.5 & 5.16 & 83.3 & 10.8 & 5.87 \\
$\quad$ Native forest & 5.0 & 0.21 & 5.91 & 85.6 & 10.2 & 4.22 \\
10-30 cm & & & & & & \\
$\quad$ Conventional coconut & 5.5 & 4.20 & 4.27 & 67.6 & 23.3 & 9.04 \\
Integrated coconut & 6.3 & 18.4 & 7.25 & 74.8 & 16.5 & 8.66 \\
$\quad$ Citrus & 6.5 & 7.80 & 3.93 & 80.1 & 13.4 & 6.51 \\
$\quad$ Native forest & 4.7 & 0.08 & 3.30 & 84.4 & 10.1 & 5.53 \\
\hline
\end{tabular}

* Mehlich 1 extractable P.

a CEC: cation exchange capacity. was analyzed by the hydrometer method, $\mathrm{pH}$ was measured using a 1:2.5 soil/solution ratio, $P$ was extracted using Mehlich 1 solution, and CEC was calculated by the sum of cations.

The study was carried out according to a fully randomized factorial design, with four types of land use (conventional coconut (Cocus nucifera L.) orchard, integrated coconut orchard, citrus orchard, and native forest) and 2 depths of sampling $(0-10 \mathrm{~cm}$ and $10-30 \mathrm{~cm})$, with 3 replicates. The conventional coconut orchard was managed without any conservation practices, using mineral fertilization (NPK), mechanical and chemical weed control, and micro-sprinkler irrigation $(4.0 \mathrm{~mm}$ of water). The integrated coconut orchard was managed with mineral fertilization and conservation practices that included organic fertilization (castor bean cake, cow manure), leguminous cover crops, and mulching. The main crop residues were dispersed on the soil surface, and irrigation employed a micro-sprinkler system ( $4.0 \mathrm{~mm}$ of water). The citrus orchard (Citrus sinensis L. Osbeck) was conventionally managed, with application of mineral fertilizer and pesticides. Weeds were controlled using tillage operations, and irrigation was performed via central pivot $(4.0 \mathrm{~mm}$ of water). The native vegetation was a remnant of the Atlantic Forest. The orchards were implemented in 1998.

Each experimental area was divided into three plots of $100 \mathrm{~m}^{2}$. In each plot, ten soil samples were randomly collected at each depth, and mixed to obtain a composite soil sample. The soil samples were homogenized, and transported in plastic bags to the laboratory, where they were air dried, sieved through a 2-mm screen, and stored prior to analysis.

\subsection{Chemical fractionation of soil organic matter}

The chemical fractionation was carried out following the method proposed by the International Humic Substances Society (IHSS) (Hayes et al., 1989) to obtain humin (H), humic acid (HA), and fulvic acid (FA) fractions, based on the solubility in acid and alkali. Total soil organic $C$ (TOC) and the $C$ contents of these fractions were determined according to Yeomans and Bremner (1988). The relationships $\mathrm{HA} / \mathrm{FA}$ and $(\mathrm{HA}+\mathrm{FA}) / \mathrm{H}$ were also calculated. The degree of humification was calculated using the formula $(\mathrm{HA}+\mathrm{FA}+\mathrm{H}) / \mathrm{TOC} \times 100$.

Soil total $\mathrm{N}$ was determined by the Kjeldahl method, as described by Bremner and Mulvaney (1982).

\subsection{Statistical analysis}

The data were analyzed following complete randomized design and using subplots. The soil use types and sampling depths were considered as primary and secondary effects, respectively. The results were submitted to variance analysis for identification of relevant effects, and the means were compared using the Tukey test $(\mathrm{P}<0.50)$. All analyses were performed using SISVAR software, version 5.0 (Fereira, 2003).

\section{Results and discussion}

\subsection{Total soil organic matter and stratification ratio}

Total soil organic matter (SOM) concentrations in the $0-10 \mathrm{~cm}$ soil layer differed significantly among land uses (Fig. 1), and followed the order: integrated coconut $>$ native forest $>$ citrus $=$ conventional coconut. Considering the soil of the native forest as a reference, the integrated coconut orchard showed an increase in SOM of approximately $37 \%$. On the other hand, in the conventional coconut and citrus orchards the SOM concentrations were reduced by almost $40 \%$. This was mainly because the different soil uses and managements affected the inputs of organic residues. Even within 


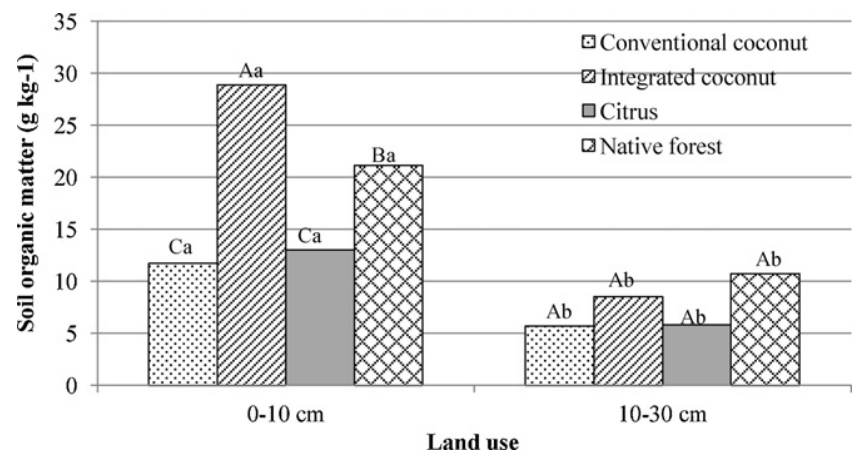

Fig. 1. Soil organic matter under different land uses, at different soil depths. Means followed by the same uppercase letter (for a given soil depth), and lowercase letter (for a given land use) are not significantly different using Tukey's test at $p<0.05$.

the same land use (as was the case for the two coconut orchards), SOM concentrations can be very different as a result of different management practices. In the integrated coconut orchard, the soil was cultivated using conservation practices that included leguminous cover crop (Pueraria phaseoloides Benth), mulching, and frequent inputs of organic and inorganic amendments, which also improved plant biomass production and consequently contributed to greater amounts of residues added to the soil. These mimicked natural systems by increasing residue returns and minimizing $C$ removal, both of which are recognized as important components of sustainable systems (Lal, 2008). These practices were not applied in the conventional coconut and citrus orchards. The differences observed across land uses can also be attributed to differences in microclimate, vegetation canopy, and litter input (Yao et al., 2010).In the $10-30 \mathrm{~cm}$ soil layer, SOM concentrations were significantly lower than in the $0-10 \mathrm{~cm}$ layer, with values in the order: native forest $=$ integrated coconut $>$ citrus $=$ conventional coconut. The results obtained here differed from those of Schroth et al. (2002), who reported no significant difference in C concentrations below $10 \mathrm{~cm}$ depth. Their study showed that the effect of forest conversion to crops, as a result of agricultural activities, was largely restricted to the topsoil.Most of the SOM content was concentrated near the soil surface $(0-10 \mathrm{~cm})$, as shown by the stratification ratio, which varied from 2.0 to 3.4 (Fig. 2). Accumulation of SOM at the soil surface was a result of surface placement of crop residues, together with a lack of soil disturbance that kept the residues isolated from the rest of the soil profile. The SOM stratification ratio was greater under integrated coconut cultivation compared with other land uses. According to Schnabel et al. (2001), stratification of SOM pools with soil depth is common in many natural ecosystems, such as forests, as well as in managed grasslands. Besides surface placement of organic

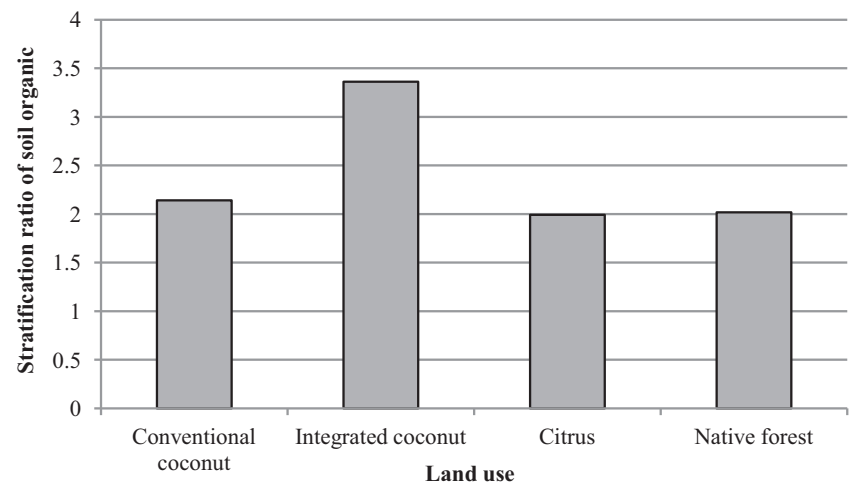

Fig. 2. Stratification ratio of soil organic carbon under different land uses. residues, undisturbed soils offer a suboptimal decomposition environment, thus causing accumulation of SOM at the soil surface (Franzluebbers, 2002).

However, care must be taken when evaluating the SOM stratification ratio as an indicator of soil quality, because a high stratification ratio does not always reflect good soil quality. High SOM stratification ratios are expected to indicate relatively undisturbed soil with good water infiltration capacity, aggregate stability, microbial activity, and nutrient supply (Franzluebbers, 2002). In the present work, this was as expected for the native forest soil. However, the conventional coconut and citrus orchard soils also presented high SOM stratification ratios, but this time as a result of soil compaction (data not shown), which reduced the rate of residue decomposition.

\subsection{Soil total nitrogen}

Soil total nitrogen (TN) is an important component of SOM, and greatly influences SOM decomposition and humification rates. TN concentrations varied widely among land uses (from 0.58 to $1.14 \mathrm{~g} \mathrm{~kg}^{-1}$ in the $0-10 \mathrm{~cm}$ layer and from 0.29 to $0.55 \mathrm{~g} \mathrm{~kg}^{-1}$ in the $10-30 \mathrm{~cm}$ layer) (Fig. 3). Total $\mathrm{N}$ values were greater at the soil surface than at depth (Fig. 3). The soil under integrated coconut cultivation showed best results, presenting 34\% more TN than the native forest soil, probably as a result of good management practices and application of $\mathrm{N}$ as both inorganic and organic amendments. The presence of leguminous plant species as cover crops, frequent inputs of organic residue (cow manure and castor bean cake), and retention of plant residues on the soil surface were some of the management practices that contributed to higher levels of soil total N. Under natural conditions, soil TN is controlled by climate and vegetation. In tropical soils, TN varies from 0.02 to $0.40 \%$, and is mainly (95\%) present in organic forms (Stevenson, 1994). The present results were therefore within the normal range (0.03-0.14\%). On the other hand, very low TN concentrations were observed in the conventional coconut orchard soil. This site was frequently treated with herbicides to control weeds, and no residue management was employed. TN concentrations reduced significantly with soil depth, following the $C$ trend.

\subsection{Degree of humification of soil organic matter}

The degree of humification of SOM is a measure of the proportions of humic and non-humic substances. Non-humic substances are labile compounds with relatively rapid turnover in soil, and are readily utilized as substrates by soil microorganisms (Masciandaro and Ceccanti, 1999). Humic substances are more stable organic compounds that make up a significant portion of the total organic C and $\mathrm{N}$ in soil (Lal, 1994).

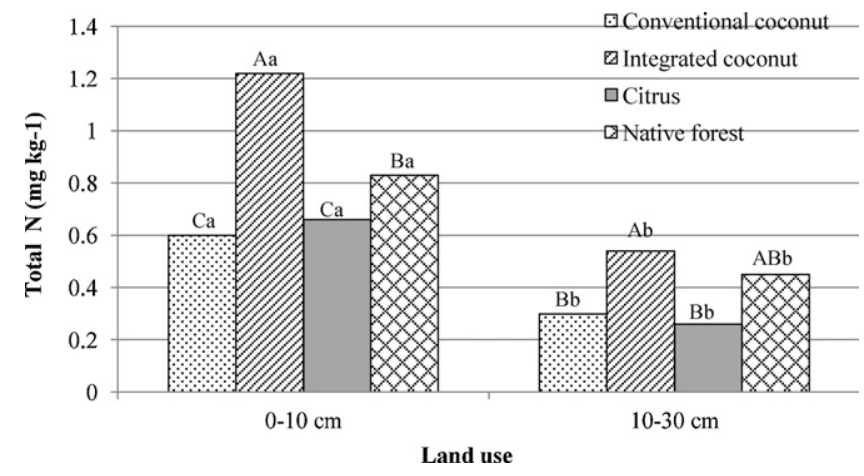

Fig. 3. Soil total nitrogen under different land uses, at different soil depths. Means followed by the same uppercase letter (for a given soil depth), and lowercase letter (for a given land use) are not significantly different using Tukey's test at $p<0.05$. 


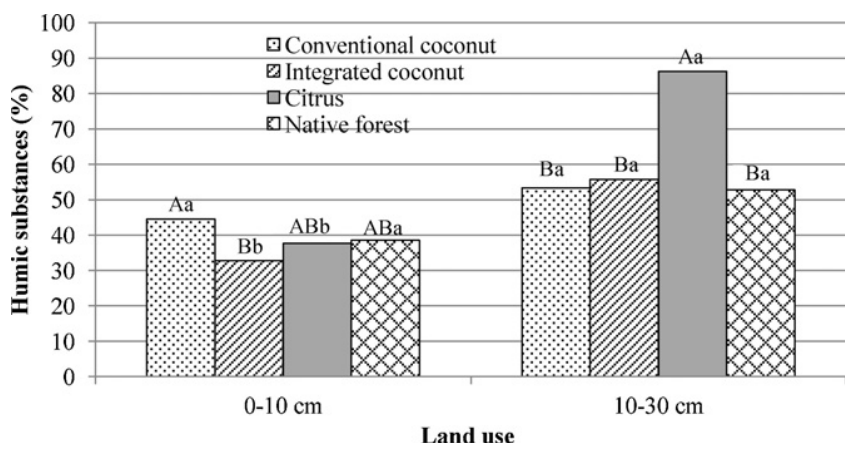

Fig. 4. Percentages of total humic substances in soils under different uses. Means followed by the same uppercase letter (for a given soil depth), and lowercase letter (for a given land use) are not significantly different using Tukey's test at $p<0.05$.

Soils from the different land uses presented varied degrees of humification (from 23.0 to $86.3 \%$ ) (Fig. 4). Mean values followed the order: citrus $(57.4 \%)>$ conventional coconut $(51.2 \%)>$ native forest $(46.0 \%)>$ integrated coconut $(43.8 \%)$. Soils from the native forest and the integrated coconut orchard presented a lower degree of humification when compared with the other land uses. This suggests that there was a greater content of non-humic substances, probably due to non-decayed inputs. Even though these two land uses were very distinct, as far as inputs and decomposition of organic residues and microclimate are concerned, good soil quality is favored by the input of large amounts of organic residues, which contributes to improved soil physical, chemical, and biological properties (Denef et al., 2007). Considering that the total SOM content was greater in soil under native forest and in soil cultivated with coconut using the integrated management system, it can be concluded that non-humic substances comprised most of the SOM in these two areas. This labile fraction of SOM may be physically protected within soil aggregates (Milori et al., 2002), and account for the major part of soil C. In addition, the integrated coconut orchard soil was kept constantly protected with cover crops, grass, and organic residue amendments. This management practice improves soil water retention, protects soil from direct solar irradiation, and reduces temperature at the soil surface, all of which act to reduce the SOM mineralization rate. The same features were observed for the native forest soil, for the same reasons.

There was an increase in the percentage of humic substances with soil depth across all land uses. This is a common trait in most soils, especially in those from forests (Milori et al., 2002). The buildup of humic substances in subsurface layers is probably related to their recalcitrance, their adsorption by the soil mineral matrix, and their intra-aggregate occlusion (Mikutta et al., 2006). In the soil evaluated in this study, there was a natural increase in clay content from the surface $(0-10 \mathrm{~cm})$ to the subsurface layer $(10-30 \mathrm{~cm})$, which also reinforces the increase in humic substances at depth. There was also a greater proportion of fresh organic material in the surface layers as compared to the subsurface layers.

According to Teit (1991), the stability of humic substances in soils is related to the regular addition of organic matter, which determines the formation of new humic substances and their destruction due to the formation of stable humus forms. Therefore, even if there are minimal alterations in total $C$ inputs, changes in management and $\mathrm{C}$ quality, which in turn affect breakdown rates, can also have effects on C dynamics in different systems (Lal, 2008).

\subsection{Fractionation of humic substances in soil}

Concentrations of $\mathrm{C}$ in fulvic acid (FA), humic acid (HA), and humin fractions in the $0-10 \mathrm{~cm}$ and $10-30 \mathrm{~cm}$ soil layers are presented in Table 2. Mean values of FA, HA, and humin varied from 0.46 to $1.08 \mathrm{~g} \mathrm{~kg}^{-1}, 0.41$ to $0.75 \mathrm{~g} \mathrm{~kg}^{-1}$, and 1.60 to $2.52 \mathrm{~g} \mathrm{~kg}^{-1}$, respectively. As expected, humin contents were higher than those of the HA and FA fractions, for all land uses (Table 2). The humic substances of forest soils are characterized by higher content of FA than HA (Guggenberger and Zech, 1994), as observed in this study.

Significant differences between the soils in terms of humin content were only observed for the $0-10 \mathrm{~cm}$ soil layer (integrated coconut $=$ native forest $>$ citrus $=$ conventional coconut $).$ The humin fraction is less prone to change with management practices, because it is the most stable and recalcitrant fraction (Stevenson, 1994). Humin concentrations decreased significantly with depth for all land uses, with the exception of the citrus orchard soil. A higher concentration of $C$ in the humin fraction of the soil surface layer could be related to intensive microbial activity and consequently a higher SOM decomposition rate. Furthermore,

Table 2



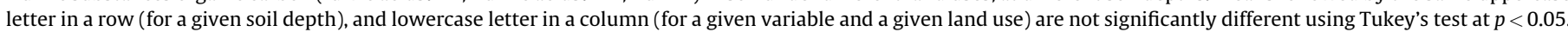

\begin{tabular}{|c|c|c|c|c|c|}
\hline \multirow[t]{2}{*}{ Humic substances $\left(\mathrm{g} \mathrm{kg}^{-1}\right)$} & \multirow[t]{2}{*}{ Soil depth $(\mathrm{cm})$} & \multicolumn{4}{|l|}{ Land use } \\
\hline & & Conventional coconut & Integrated coconut & Citrus & Native forest \\
\hline FA & $\begin{array}{r}0-10 \\
10-30\end{array}$ & $\begin{array}{l}0.56 \mathrm{Ba} \\
0.37 \mathrm{Cb}\end{array}$ & $\begin{array}{l}0.60 \mathrm{Ba} \\
0.65 \mathrm{Ba}\end{array}$ & $\begin{array}{l}0.69 \mathrm{Ba} \\
0.52 \mathrm{Bb}\end{array}$ & $\begin{array}{l}1.16 \mathrm{Aa} \\
1.01 \mathrm{Aa}\end{array}$ \\
\hline HA & $\begin{array}{r}0-10 \\
10-30\end{array}$ & $\begin{array}{l}0.59 \mathrm{Ba} \\
0.49 \mathrm{Aa}\end{array}$ & $\begin{array}{l}0.90 \mathrm{Aa} \\
0.40 \mathrm{Ab}\end{array}$ & $\begin{array}{l}0.43 \mathrm{Ba} \\
0.40 \mathrm{Aa}\end{array}$ & $\begin{array}{l}0.92 \mathrm{Aa} \\
0.58 \mathrm{Ab}\end{array}$ \\
\hline Humin & $\begin{array}{r}0-10 \\
10-30\end{array}$ & $\begin{array}{l}2.17 \mathrm{BCa} \\
1.14 \mathrm{Ab}\end{array}$ & $\begin{array}{l}3.37 \mathrm{Aa} \\
1.67 \mathrm{Ab}\end{array}$ & $\begin{array}{l}1.80 \mathrm{Ca} \\
1.41 \mathrm{Aa}\end{array}$ & $\begin{array}{l}2.82 \mathrm{ABa} \\
1.53 \mathrm{Ab}\end{array}$ \\
\hline HA/FA & $\begin{array}{r}0-10 \\
10-30\end{array}$ & $\begin{array}{l}1.06 \mathrm{Ba} \\
1.31 \mathrm{Aa}\end{array}$ & $\begin{array}{l}1.53 \mathrm{Aa} \\
0.61 \mathrm{Bb}\end{array}$ & $\begin{array}{l}0.62 \mathrm{Aa} \\
0.73 \mathrm{Aa}\end{array}$ & $\begin{array}{l}0.79 \mathrm{Ca} \\
0.58 \mathrm{Ba}\end{array}$ \\
\hline $\mathrm{HA}+\mathrm{FA} /$ Humin & $\begin{array}{r}0-10 \\
10-30\end{array}$ & $\begin{array}{l}0.54 \mathrm{ABb} \\
0.77 \mathrm{Ba}\end{array}$ & $\begin{array}{l}0.44 \mathrm{Ba} \\
0.64 \mathrm{Ba}\end{array}$ & $\begin{array}{l}0.62 \mathrm{ABb} \\
0.54 \mathrm{Aa}\end{array}$ & $\begin{array}{l}0.74 \mathrm{Ab} \\
1.04 \mathrm{Aa}\end{array}$ \\
\hline $\mathrm{HA}+\mathrm{FA} / \mathrm{TOC}$ & $\begin{array}{r}0-10 \\
10-30\end{array}$ & $\begin{array}{l}0.15 \mathrm{Ab} \\
0.25 \mathrm{Aa}\end{array}$ & $\begin{array}{l}0.10 \mathrm{Bb} \\
0.21 \mathrm{Aa}\end{array}$ & $\begin{array}{l}0.14 \mathrm{Ab} \\
0.24 \mathrm{Aa}\end{array}$ & $\begin{array}{l}0.17 \mathrm{Ab} \\
0.26 \mathrm{Aa}\end{array}$ \\
\hline$(\mathrm{HA}+\mathrm{FA}+$ Humin $) / \mathrm{TOC}$ & $\begin{array}{r}0-10 \\
10-30\end{array}$ & $\begin{array}{l}0.44 \mathrm{Aa} \\
0.58 \mathrm{ABa}\end{array}$ & $\begin{array}{l}0.33 \mathrm{Bb} \\
0.54 \mathrm{Ba}\end{array}$ & $\begin{array}{l}0.38 \mathrm{ABb} \\
0.76 \mathrm{Aa}\end{array}$ & $\begin{array}{l}0.40 \mathrm{Aa} \\
0.52 \mathrm{Ba}\end{array}$ \\
\hline $\mathrm{C} / \mathrm{N}$ & $\begin{array}{r}0-10 \\
10-30\end{array}$ & $\begin{array}{l}12.8 \mathrm{Ba} \\
11.9 \mathrm{Aa}\end{array}$ & $\begin{array}{l}14.7 \mathrm{Aa} \\
9.00 \mathrm{Ab}\end{array}$ & $\begin{array}{l}11.7 \mathrm{Ba} \\
12.9 \mathrm{Aa}\end{array}$ & $\begin{array}{l}14.4 \mathrm{Aa} \\
12.8 \mathrm{Aa}\end{array}$ \\
\hline
\end{tabular}


humin constitutes a major part of the total organic carbon (TOC), and has an intimate association with the soil mineral fraction (Moraes et al., 2011).

Since the concentrations of humic substances are influenced by the amounts of organic residue inputs and TOC, calculation was made of the proportion of each fraction (fulvic acids, humic acids, and humin) (Fig. 5). The overall trend was humin (61.0\%) $>$ FA $(21.4 \%)>$ HA (17.6\%). More FA than HA were observed in all soils, with the exception of the conventional coconut orchard soil. The frequent input of fresh organic residues, especially in the case of the native forest soil, contributed to the higher proportion of FA. Irrespective of soil depth, the FA content followed the order: native forest $=$ citrus $>$ integrated orchard $=$ conventional coconut. It is interesting to note that although the citrus and conventional coconut orchards presented similar concentrations of SOM (Fig. 1), the distribution of humic fractions was very different (Fig. 5). The proportion of FA was significantly higher in the citrus orchard soil than in the conventional coconut soil. The inverse occurred for the HA. The HA fraction did not differ significantly among soil uses. Maintenance of high levels of SOM, especially the more soluble fractions, in the cultivated soils investigated in this study would be a very hard task, due to the sandy nature of the soil combined with the warm climate of the region.

The humin fraction proportion in the integrated orchard was higher than in the native forest soil, and did not differ among the cultivated soils, indicating the occurrence of a more intensive decomposition process in the agricultural soils. This result confirms the assertion that total SOM is not a very sensitive indicator for evaluation of changes in soil quality as a function of soil management, because the predominant fraction is the more recalcitrant pool.

\subsection{Ratios involving humic substances}

The relationships between different components of humic substances can be of great interest when studying the effect of land use and soil management on soil quality.

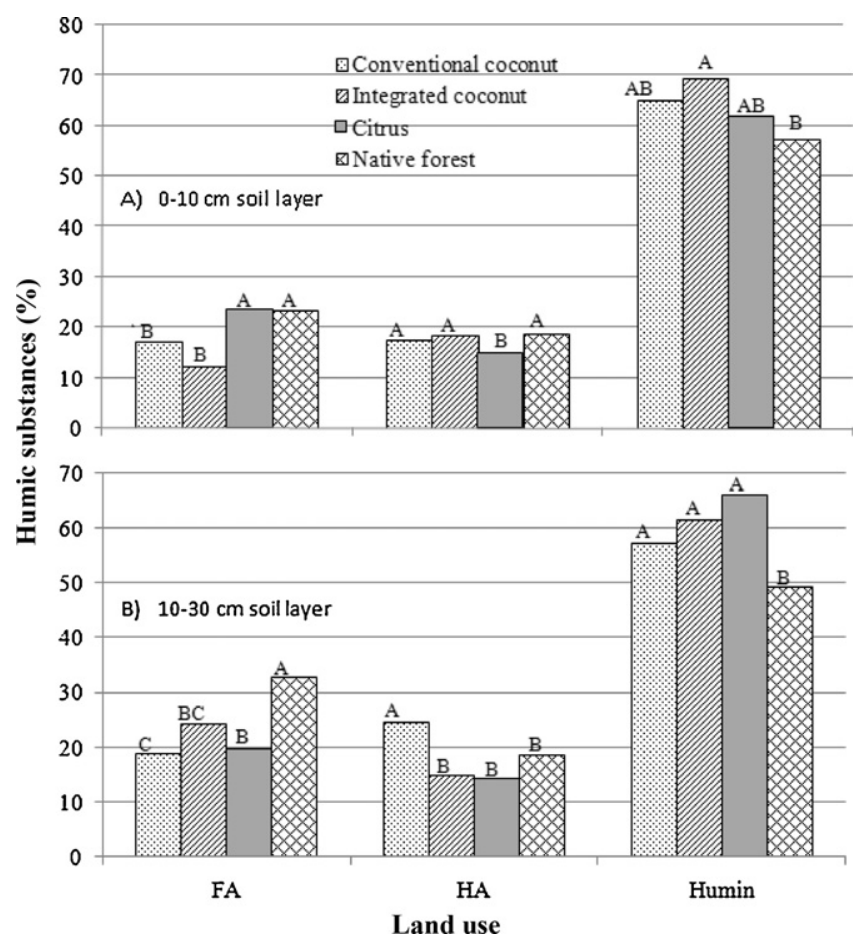

Fig. 5. Percentages of fulvic acids, humic acids, and humin in soil organic matter under different land uses, at 0-10 cm soil depth (A) and at 10-30 cm soil depth (B) Means followed by the same letter, within each variable, are not significantly different using Tukey's test at $p<0.05$.
The ratio between humic and fulvic acids (HA/FA) reflects the mobility of soil organic carbon. A HA/FA ratio near 1 is indicative of good quality organic material that could enhance soil physical properties and improve plant growth. A HA/FA ratio $>1$ indicates loss of the more labile FA fraction, a situation very common in sandy soils. In this study, the HA/FA ratio varied from 0.62 to 1.53 $(0-10 \mathrm{~cm})$, and from 0.58 to $1.31(10-30 \mathrm{~cm})$, and showed some persistence of FA in soil under citrus cultivation and native forest (Table 2). More FA than HA indicates low humification rates. Although the conservation management practices applied in the integrated coconut orchard contributed to an increase in the total SOM concentration, degradation rates were high due to the quality of organic residue added, as well as the high $\mathrm{N}$ content, which increased the loss of the more labile fraction in the surface layer.

The ratio between the combined humic and fulvic acids and humin ((HA + FA)/humin) can provide information about the loss of SOM through the soil profile. For the different land uses, the ratio varied from 0.44 to $0.75(0-10 \mathrm{~cm})$, and from 0.54 to $1.05(10-$ $30 \mathrm{~cm}$ ), indicating the predominant presence of humin (Table 2). The broad range of values could be related to high heterogeneity of the organic residues applied to the different sites, as well as differences in the SOM humification process. The values of the $(\mathrm{HA}+\mathrm{FA}) / \mathrm{H}-\mathrm{C}$ ratio were lower than 1 across all land uses, indicating a greater proportion of the humin fraction. These values could also be related to strong interaction between SOM and the soil mineral phase, resulting in high stability of SOM in the more recalcitrant humin fractions (Canellas et al., 2008).

The rates of decomposition of organic residues and, as a consequence, the accumulation of SOM, are influenced by the $\mathrm{C} / \mathrm{N}$ ratio, which varied from 9.0 to 14.4 . The highest $\mathrm{C} / \mathrm{N}$ ratio was found for the native forest soil. In the cultivated areas, frequent inputs of $\mathrm{N}$ fertilizers contributed to lower $\mathrm{C} / \mathrm{N}$ ratios, due to stimulation of residue decomposition. This was confirmed by the reduced TOC and C concentrations in the SOM fractions of soils from the cultivated areas.

\section{Conclusions}

The use of SOM chemical fractions to evaluate changes in soil C dynamics due to agricultural use was more effective than determination of total SOM. The distribution of $\mathrm{C}$ among the different fractions changed when forest soil was brought into cultivation, due to the amount and quality of organic materials added to the soils. Amongst the most labile fractions, fulvic acid predominated, resulting in a HA/FA ratio $<1$ for most land uses. The predominance of a higher percentage of fulvic acids, as compared to humic acids, indicated either a slow rate of SOM decomposition, or frequent inputs of fresh organic residues. Fulvic acid was effective in discriminating changes in land use, due to its characteristic lability. On the other hand, the humin fraction was stable, and similar for the different cultivated soils. Compared to the native forest soil, cultivation increased the proportion of the recalcitrant fraction, and led to a reduction in the labile fraction of SOM. Sustainable management practices should therefore be employed in order to achieve soil stability and biological productivity.

\section{References}

Ashagrie, Y., Zech, W., Guggenberger, G., Mamo, T., 2007. Soil aggregation and total and particulate organic matter following conversion of native forests to continuous cultivation in Ethiopia. Soil and Tillage Research 94, 101-108.

Bayer, C., Mielniczuk, J., Martin-Neto, L., Ernani, P.R., 2002. Stocks and humification degree of organic matter fractions as affected by no-tillage on a subtropical soil. Plant Soil 238, 133-140.

Benites, V.M., Madari, B., Machado, P.L.O.A., 2003. Extração e fracionamento quantitativo de substâncias húmicas do solo: Um procedimento simplificado de baixo custo. Comunicado Técnico 16. EMBRAPA Solos, Rio de Janeiro, 7 pp. 
Bremner, J.M., Mulvaney, C.S., 1982. Nitrogen total. In: Page, A.L., Miller, R.H., Keeney, D.R. (Eds.), Methods of Soil Analysis: Chemical and Microbiological Properties, 2nd ed., vol. 2. Am. Soc. Agronomy/Soil. Sci. Soc. Am., Madison, pp. 595-624.

Canellas, L.P., Teixeira Jr., L.R.L., Dobbss, L.B., Silva, C.A., Médici, L.O., Zandonadi, D.B., Façanha, A.R., 2008. Humic acids cross interactions with root and organic acids. Annals of Applied Biology 153, 157-166.

Denef, K., Zotarelli, L., Boddey, R.M., Six, J., 2007. Microaggregate-associated carbon as a diagnostic fraction for management induced changes in soil organic carbon in two Oxisols. Soil Biology and Biochemistry 39, 1165-1172.

Fereira, D.F., 2003. Sisvar Version 4.2. Federal University of Lavras, Lavras.

Follett, R.F., 2001. Soil management concepts and carbon sequestration in cropland soils. Soil and Tillage Research 61, 77-92.

Franzluebbers, A.J., 2002. Soil organic matter stratification ratio as an indicator of soil quality. Soil and Tillage Research 66, 95-106.

Guggenberger, G., Zech, W., 1994. Dissolved organic carbon in forest floor leachates: simple degradation products or humic substances? Science of the Total Environment 152, 37-47.

Hayes, M.H., McCarthy, P., Malcom, R.L., Swift, R.S., 1989. Structures of humic substances: the emergence of forms. In: Hayes, M.H., McCarthy, P., Malcom, R.L., Swift, R.S. (Eds.), Humic Substance II: In Search of Structure: Setting the Scene. John Wiley \& Sons, New York, pp. 3-31.

Haynes, R.J., 2005. Labile organic matter fractions as central components of the quality of agricultural soils. Advances in Agronomy 85, 221-268.

Kiem, R., Kögel-Knabner, I., 2003. Contribution of lignin and polysaccharides to the refractory carbon pool in C-depleted arable soils. Soil Biology and Biochemistry 35, 101-118.

Lal, R., 1994. Tillage effects on soil degradation, soil resilience, soil quality, and sustainability. Soil and Tillage Research 27, 1-8.

Lal, R., 2006. Soil carbon sequestration in Latin America. In: Lal, R., Cerri, C.C., Bernoux, M., Etcheves, J., Cerri, E. (Eds.), Carbon Sequestration in Soils of Latin America. Food Products Press, New York, pp. 49-64.

Lal, R., 2008. Crop residues as soil amendments and feedstock for bioethanol production. Waste Management 28, 747-758.

McCarthy, P., 2001. The principles of humic substances. Soil Science 166, 738-751.

Masciandaro, G., Ceccanti, B., 1999. Assessing soil quality in different agro-ecosystems through biochemical and chemical-structural properties of humic substances. Soil and Tillage Research 51, 129-137.

Mikutta, R., Kleber, M., Tom, M.S., Jahn, R., 2006. Stabilization of soil organic matter: association with minerals or chemical recalcitrance? Biogeochemistry $77,25-$ 56.

Milori, D.M.B.P., Martin-Neto, L., Bayer, C., Mielniczuk, J., Bagnato, V.S., 2002. Humification degree of soil humic acids determined by fluorescence spectroscopy. Soil Science 167, 739-749.

Moraes, G.M., Xavier, F.A.S., Mendonca, E.S., Araujo Filho, J.A., Oliveira, T.S., 2011. Chemical and structural characterization of soil humic substances under agro- forestry and conventional systems. Brazilian Journal of Soil Science 35, 15971608.

Navarrete, I.A., Tsutsuki, K., 2008. Land-use impact on soil carbon, nitrogen, neutral sugar composition and related chemical properties in a degraded Ultisol derived from volcanic materials in Leyte, Philippines. Soil Science and Plant Nutrition 54, 321-331.

Paul, E.A., Collins, H.P., Leavitt, S.W., 2001. Dynamics of resistant soil carbon of Midwestern agricultural soils measured by naturally occurring 14C abundance. Geoderma 104, 239-256.

Peel, M.C., Finlayson, B.L., McMahon, T.A., 2007. Updated world map of the KoppenGeiger climate classification. Hydrology and Earth System Sciences 11, 16331644.

Rovira, P., Vallejo, V.R., 2007. Labile, recalcitrant and inert organic matter in Mediterranean forest soils. Soil Biology and Biochemistry 39, 202-215.

Schmidt, M.W.I., Torn, M.S., Abive, S., Dittimar, T., Guggenberger, G., Janssens, I.A. Kleber, M., Kogel-Knabner, I., Lehmann, J., Manning, D.A.C., Nannipieri, P., Rasse, D.P., Weiner, S., Trumbore, S.E., 2011. Persistence of soil organic matter as an ecosystem property. Nature 478, 49-56.

Schnabel, R.R., Franzluebbers, A.J., Stout, W.L., Sanderson, M.A., Stuedemann, J.A., 2001. The effects of pasture management practices. In: Follett, R.F., Kimble J.M., Lal, R. (Eds.), The Potential of US Grazing Lands to Sequester Carbon and Mitigate the Greenhouse Effect. Lewis Publishers, Boca Raton, FL, pp. 291-322.

Schroth, G., Sammya, A.D.A., Teixeira, W.G., Haag, D., Lieberei, R., 2002. Conversion of secondary forest into agroforestry and monoculture plantation in Amazonia: consequences for biomass, litter and soil carbon stocks after 7 years. Forest Ecology and Management 163, 131-150.

Spaccini, R., Piccolo, A., Haberhauer, G., Gerzabek, M., 2006. Transformation of organic matter from maize residues into labile and humic fractions of three European soils as revealed by $13 \mathrm{C}$ distribution and CPMAS-NMR spectra. European Journal of Soil Science 51, 583-594.

Stevenson, F.J., 1994. Humus Chemistry: Genesis, Composition Reactions, 2nd ed. John Wiley \& Sons, New York, p. 496.

Sutton, R., Sposito, G., 2005. Molecular structure in soil humic substance: new view. Environmental Science and Technology 39, 9009-9016.

Teit, R., 1991. Soil Organic Matter Biological and Ecological Effects. Nauka, Moskva, $395 \mathrm{p}$.

Wendling, B., Jucksch, I., Mendonca, E.S., Alvarenga, R.C., 2010. Organic-matter pools of soil under pines and annual cultures. Communications in Soil Science and Plant Analysis 41, 1707-1722.

Yao, M.K., Angui, P.K.T., Konate, S., Tondoh, J.E., Tano, Y., Abbadie, L., Benest, D., 2010 Effects of land use types on soil organic carbon and nitrogen dynamics in midwest Côte d'Ivoire. European Journal of Scientific Research 40, 211-222.

Yeomans, J.C., Bremner, J.M., 1988. A rapid and precise method for routine determination of organic carbon in soil. Communications in Soil Science and Plant Analysis 19, 1467-1476. 